\title{
Development of a Low Temperature Sol-Gel-Derived Titania-Silica Implant Coating
}

\author{
Virpi Ääritalo ${ }^{1,5}$, Ville Meretoja ${ }^{1}$, Teemu Tirri ${ }^{1}$, Sami Areva ${ }^{2}$, Timo Jämsä ${ }^{3}$, Juha Tuukkanen ${ }^{4}$, \\ Ari Rosling ${ }^{5}$, Timo Närhi ${ }^{1}$
}

\begin{abstract}
${ }^{1}$ Department of Prosthetic Dentistry, Institute of Dentistry, University of Turku, Lemminkäisenkatu, Turku, Finland; ${ }^{2}$ Turku Centre for Biomaterials, Itäinen Pitkäkatu 4B, Turku, Finland; ${ }^{3}$ Department of Medical Technology, University of Oulu, Oulu, Finland; ${ }^{4}$ Department of Anatomy and Cell Biology, University of Oulu, Oulu, Finland; ${ }^{5}$ Laboratory of Polymer Technology, Åbo Akademi University, Biskopsgatan, Turku, Finland.
\end{abstract}

Email: virpi.aaritalo@abo.fi

Received May 20 $0^{\text {th }}, 2010$; revised June $13^{\text {th }}, 2010$; accepted June $28^{\text {th }}, 2010$.

\begin{abstract}
Objective of this study was to develope low temperature sol-gel coatings for shape memory metal (NiTi) and evaluate their biocompatibility on NiTi suture material. A series of low temperature $\mathrm{TiO}_{2}$ and $\mathrm{TiO}_{2}-\mathrm{SiO}_{2}$ sol-gel coatings were prepared on glass substrates. The silica content of $\mathrm{TiO}_{2}-\mathrm{SiO}_{2}$ coatings ranged from 0 to $30 \mathrm{~mol} \%$. The coatings were also prepared with polyethyleneglycol (PEG). The contact angle and photocatalytic activity measurements were used to evaluate the surface properties of the coatings. Stability of the coatings was tested in simulated body fluid (SBF). The $\mathrm{TiO}_{2}-\mathrm{SiO}_{2}$ 90/10 film made with PEG was more hydrophilic, showed photocatalytic activity and was crack-free after the SBF test, thus it was chosen to animal experiment as a new experimental coating. Uncoated NiTi suture and the suture coated with high temperature $\mathrm{TiO}_{2}$ were used as reference materials. NiTi sutures were inserted subcutaneously on the back of rat for four weeks. In routine histological examinations all materials showed good biocompatibility with mild inflammatory cell reaction. No significant differences in the soft tissue response among the materials were observed. Both the high and new low temperature processed sol-gel coatings remained attached on the sutures confirming the suitability of the coating technique on thin NiTi sutures.
\end{abstract}

Keywords: Sol-Gel Technique, Titania-Silica, Thin Film, Bioactive Coating, NiTi, Soft Tissue

\section{Introduction}

Sol-gel technology is a promising manufacturing method to produce bioactive materials for biomedical applications $[1,2]$. The growing interest towards sol-gel materials is based on their ability to form a tight contact with the surrounding tissues, providing a strong chemical bond with them [3-5]. The silicon has shown to have several important roles in material preparation and materials biological response. The addition of the silicon into the materials structure has shown positive effect on osteoblast response on medical implant surfaces, e.g. on hydroxyapatite [6-8] and sol-gel titania films [9-11]. The $\mathrm{TiO}_{2}-$ $\mathrm{SiO}_{2}$ sol-gel coatings have been shown to be biocompatible in vitro [9] and in vivo [12].

The nickel-titanium shape memory alloys (NiTi, Nitinol) are promising materials for surgical implants in reconstructive medicine, because of their unique shape memory effect and super-elasticity [13]. However, some adverse effects such as inferior osteogenesis process, im- paired osteonectin synthesis and increased cell death rate have also been reported [14-16]. The biocompatibility of nikel-titanium alloys may be enhanced by the protective film e.g. by thickening the natural $\mathrm{TiO}_{2}$ layer at high temperatures [17], by hydroxyapatite coating [18] or by ion implantation [19]. A sol-gel derived titania-silica coating has been found to increase the bone to implant contact and biocompatibility of NiTi intramedullary nails [12].

The sol-gel materials can be processed and applied at room temperature, but the prepared materials often need a consolidation and densification step, by which the optimal material structure and surface properties can be tailored [20-22]. The conventional methods to consolidate the sol-gel titania are heat treatment at above $400^{\circ} \mathrm{C}$ and/ or laser densification, but with these techniques the substrate material is limited to ceramics and metals. These temperatures are far too high for thermally sensitive materials, such as most polymers, thus there is a striking need for bioactive sol-gel coatings prepared at lower temperatures. 
The purpose of this study was to evaluate the possibility to lower the processing temperature of bioactive solgel derived implant coatings and to explore biologic response of the most promising coatings in soft tissue environment on NiTi suture materials.

\section{Materials and Methods}

\subsection{Preparation of Coatings}

A series of titania and titania-silica coatings were prepared on glass slides by dip-coating method. Before the coating process the glass slides were ultrasonically cleaned in acetone and in ethanol, five minutes in both solvents.

$\mathrm{TiO}_{2}-\mathrm{SiO}_{2}$ sols were prepared by mixing the following $\mathrm{TiO}_{2}$ and $\mathrm{SiO}_{2}$ sols so that the $\mathrm{TiO}_{2}-\mathrm{SiO}_{2}$ molar ratios 100/0, 90/10, 80/20 and 70/30 were obtained. $\mathrm{SiO}_{2}$ sol was prepared by mixing tetraethyl orthosilicate [TE-OS, $\left(\mathrm{Si}\left(\mathrm{OC}_{2} \mathrm{H}_{5}\right)_{4}\right]$, ethanol and water at room temperature having the $\mathrm{EtOH}: \mathrm{Si}(\mathrm{OR})_{4}$ and $\mathrm{H}_{2} \mathrm{O}: \mathrm{Si}(\mathrm{OR})_{4}$ molar ratios of 1.9 and 1.0, respectively. The prepared sol was hydrolyzed at $40^{\circ} \mathrm{C}$ for one hour. $\mathrm{TiO}_{2}$ was prepared by mixing titanium tetraisopropoxide [TIPT, $\left(\mathrm{Ti}\left(\mathrm{OC}_{3} \mathrm{H}_{7}\right)_{4}\right)$ ], ethanol, nitric acid $(65 \%)$, and water at room temperature and hydrolyzed at $40^{\circ} \mathrm{C}$ for $30 \mathrm{~min}$ having the EtOH: $\mathrm{Ti}(\mathrm{OR})_{4}, \mathrm{H}_{2} \mathrm{O}$ : $\mathrm{Ti}(\mathrm{OR})_{4}$ and $\mathrm{HNO}_{3}$ : $\mathrm{Ti}(\mathrm{OR})_{4}$ molar ratios 18.0, 1.2 and 0.33 , respectively. The prepared sols are mixed rapidly under stirring. The mixed $\mathrm{TiO}_{2}-\mathrm{SiO}_{2}$ sols were aged at $40^{\circ} \mathrm{C}$ for 24 hours and cooled to room temperature before the dipping process. Sols were also prepared with polyethylene glycol PEG $\left(\mathrm{M}_{\mathrm{w}} 600 \mathrm{~g} / \mathrm{mol}\right)$. PEG is added into the mixed sol $\left(\mathrm{m}_{\mathrm{PEG}}=\mathrm{m}_{\text {oxides }}\right)$ before aging. The compositions of the prepared mixed sols are shown in Table 1. The dipping process was carried out at ambient atmosphere at room temperature. The substrate plates were dipped into the sol and withdrawn at a speed of $0.3 \mathrm{~mm} / \mathrm{s}$. The dip-coated plates were dried at $60^{\circ} \mathrm{C}$ for one hour. The dried coatings were further treated in autoclave, 60 minutes at $121^{\circ} \mathrm{C}$. The $\mathrm{TiO}_{2}-\mathrm{SiO}_{2}$ 90/10 PEG containing coatings were also post-treated under UV-light $(254 \mathrm{~nm})$ for three hours.

Table 1. The compositions of the prepared $\mathrm{TiO}_{2}-\mathrm{SiO}_{2}$ sols

\begin{tabular}{cccc}
\hline Material & EtOH/alk & $\mathrm{H}_{2} \mathrm{O} /$ alk & $\mathrm{HNO}_{3} /$ alk \\
\hline TiSi 70/30 & 13.2 & 1.14 & 0.23 \\
TiSi 70/30 PEG & 13.2 & 1.14 & 0.23 \\
TiSi 80/20 & 14.8 & 1.16 & 0.27 \\
TiSi 80/20 PEG & 14.8 & 1.16 & 0.27 \\
TiSi 90/10 & 16.4 & 1.18 & 0.30 \\
TiSi 90/10 PEG & 16.4 & 1.18 & 0.30 \\
$\mathrm{TiO}_{2}$ & 18.0 & 1.20 & 0.34 \\
$\mathrm{TiO}_{2}$ PEG & 18.0 & 1.20 & 0.34 \\
\hline
\end{tabular}

\subsection{Surface Characterization}

The transmittance through the dip coated glass substrates was measured using the UV-Vis spectrometer in the wavelength range 300-600 $\mathrm{nm}$ [Shimadzu UV-1601]. Water contact angle of the coatings was measured by sessile drop method at room temperature by using contact angle meter CAM100 [KSV instruments Ltd., Helsinki, Finland]. The contact angle was established from six parallel measurements taken from each sample. Photocatalytic activity of the specimens was given by the degradation of methylene blue (MB). The coated glass substrates (2.5 $\mathrm{cm} \times 2.5 \mathrm{~cm})$ were immersed into $\mathrm{MB}$ aqueous solution $\left(10^{-5} \mathrm{M}\right)$. The substrates were irradiated with UV light and the changes in concentrations of $\mathrm{MB}$ in the aqueous solution were examined as a function of time from absorption spectra measured on a UV-Vis spectrophotometer [Shimadzu UV-1601] at a wavelength of $660 \mathrm{~nm}$. The concentration of methylene blue was measured over a 5 -hour period, at intervals of one hour. The reaction rate constant for photocatalytic degradation of methylene blue was obtained graphically from the relationship between natural logarithm of the normalized absorbance, $\ln \left(A / A_{0}\right)$, and reaction time [23]. The kinetic may be expressed as follow,

$$
\ln \left(\frac{A}{A_{0}}\right)=k t
$$

where $k$ is the apparent reaction rate constant (1/hours), $A_{0}$ and $A$ are the initial absorbance and the reaction absorbance of methylene blue, respectively and $t$ is time. The initial absorbance value is measured from the methylene blue solution after one hour immersion in dark. The rate for the decomposition reaction of the MB aqueous solutions was obtained one time for each coating. An example for absorbance curves is shown in Figure 1. The resulted decomposition rates (1/hours) are given per area

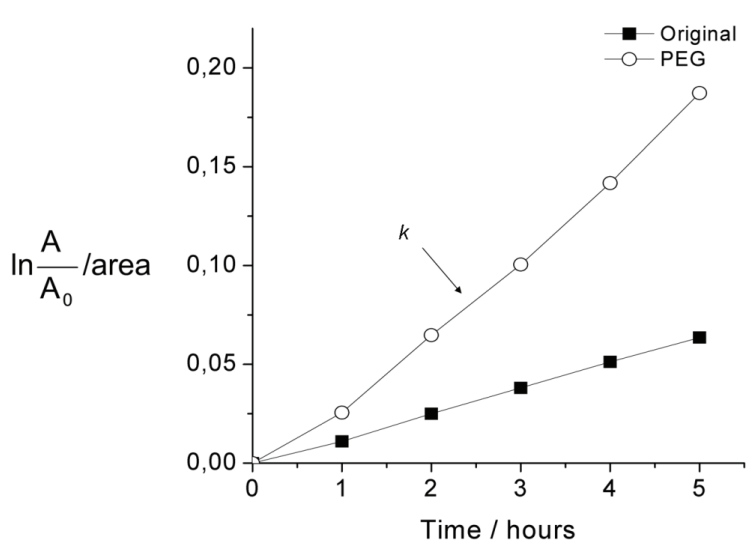

Figure 1. Calculation of the photocatalytic activity $(k)$ $\left(\right.$ hour ${ }^{-1} \mathrm{~cm}^{-2}$ ) from methylene blue time-absorbance curves. Curves are only shown for $\mathrm{TiO}_{2}-\mathrm{SiO}_{2}$ 90/10 films; original and PEG containing, though in figure 4 all $k$-values are presented 
$\left(\mathrm{cm}^{2}\right)$, because the specimens are cut from the glass slides (average size $2.5 \mathrm{~cm} \times 2.5 \mathrm{~cm}$ ). The stability of the coatings was tested by immersing the samples $(10 \times 10$ $\mathrm{mm}^{2}$ ) into $15 \mathrm{ml}$ of simulated body fluid (SBF) [24] at $37^{\circ} \mathrm{C}$ for three weeks. Two parallel samples were immersed in closed polyethylene tubes under a shaking water bath at a constant temperature of $37^{\circ} \mathrm{C}$. After immersion the samples were removed from the fluid, gently rinsed with distilled water and dried at $40^{\circ} \mathrm{C}$ before the surface analysis. The surfaces were analysed with optical microscope.

\section{Animal Experiment}

\subsection{Implant Materials}

The NiTi (Ni 55.5-Ti 44.5 weight \%) suture material was ground by silicon carbide papers having 1200 grits and the suture was ultrasonically washed $5 \mathrm{~min}$ in acetone and $5 \mathrm{~min}$ in ethanol before dipping. Two different solgel coated NiTi sutures were prepared: $\mathrm{TiO}_{2}$ heat treated at $500^{\circ} \mathrm{C}$ and novel low temperature $\mathrm{TiO}_{2}-\mathrm{SiO}_{2}$ 90/10 prepared with $\mathrm{PEG}$, which exhibited the most suitable properties for implant coating (see materials characterization section). The uncoated NiTi suture was used as reference. The average diameter of NiTi suture is $220 \mu \mathrm{m}$. The conventional $\mathrm{TiO}_{2}$ sol-gel coating was prepared by sol-gel dip-coating technique as described by Areva and co-workers [3]. Briefly, titanium tetraisopropoxide [TIPT, $\left.\mathrm{Ti}\left(\left(\mathrm{CH}_{3}\right)_{2} \mathrm{CHO}\right)_{4}\right]$ was dissolved into ethanol and mixed with the solution containing ethyleneglycolmonoethylether $\left(\mathrm{C}_{2} \mathrm{H}_{5} \mathrm{OCH}_{2} \mathrm{OH}\right)$, deionized water, fuming hydrochloric acid $(\mathrm{HCl}, 37 \%)$ and ethanol. The sol was aged for 24 hours at $0^{\circ} \mathrm{C}$ before dipping. The number of coating layers was five and every layer was heat treated $15 \mathrm{~min}-$ utes at $500^{\circ} \mathrm{C}$. The $\mathrm{TiO}_{2}-\mathrm{SiO}_{2}$ 90/10 PEG sol was prepared as described in this work. The $\mathrm{TiO}_{2}-\mathrm{SiO}_{2}$ film was used as monolayer. The prepared film was autoclaved 60 minutes at $121^{\circ} \mathrm{C}$ and UV-light treated for three hours. The implant sutures were sterilized with gamma radiation (minimum, $25 \mathrm{kGy}$ ). The morphology of implant surfaces was examined with SEM [JEOL Scanning Electron Microscope JSM-5500].

\subsection{Surgical Procedure}

Four adult Sprague-Dawley rats were used for the study. The experiment was accepted by The Ethical Committee for Animal Experiments at the Turku University, Finland (license \#1420/04) and national guidelines for the care and use of laboratory animals were followed. Operations were performed under general anesthesia induced by subcutaneous injection of fentanyl citrate/fluanisone (Hypnorm ${ }^{\circledR}$, Janssen Pharmaceutica, Beerse, Belgium) and midatzolam (Dormicum ${ }^{\circledR}$, Roche, Basel, Switzerland). The operation area was shaved and disinfected with chlorhexidine gluconate solution (Klorhexol®, Leiras Ltd, Turku,
Finland).

The two centimeters long experimental materials were inserted subcutaneously on the back of each rat via six one centimeter skin incisions. Skin wound was closed with individual resorbable sutures (Vicryl 3-0, Johnson \& Johnson Intl, Brussels, Belgium). Animals were sacrificed after four weeks using $\mathrm{CO}_{2}$ suffocation. Implants were retrieved with 2 to $4 \mathrm{~mm}$ soft tissue margin and fixed in $4 \%$ buffered formalin at $8^{\circ} \mathrm{C}$ for two weeks.

\subsection{Histological and Histomorphometrical Evaluation}

Fixed specimens were dehydrated in a graded series of ethanol and embedded in light curing resin (Technovit 7200, Exakt, Kulzer, Norderstedt, Germany). The specimens were cut and ground down to $20 \mu \mathrm{m}$ and stained with haematoxylin and eosin (HE) for light microscope analysis. Sections were histologically evaluated for fibrous tissue capsule formation, inflammatory reaction and foreign body reaction using light microscope.

Histomorphometrical grading was done according to the criteria by Jansen and co-workers [25]. Briefly, capsule thickness, tissue morphology and implant to tissue interface were rated from 0 (the least favorable) to 4 (the most favourable). The capsule thickness measurement was based on the observed number of fibroblasts. The qualitative rating of the capsule consisted of rating the tissue morphology (fibrous tissue, maturity, presence of connective tissue or fat tissue) and cellularity (presence of fibroblasts, macrophages, giant cells and other inflammatory cells). Direct contact was evaluated from four cross sectional sectors of the implants and graded according to the number of sectors from which immediate implant to tissue contact was detected. An implant was determined to be in direct contact if no visible gap could be observed between the connective tissue and implant surface at magnification $\times 200$. Statistical analysis was performed with an SPSS v.11.0 software package (SPSS Inc., IL). Data were analyzed with one-way ANOVA followed by Tukey's post-hoc test. Differences were considered significant at $95 \%$ confidence level.

\section{Results}

\subsection{Surface Characteristics}

$\mathrm{TiO}_{2}$ and $\mathrm{TiO}_{2}-\mathrm{SiO}_{2}$ sols with 10,20 and $30 \mathrm{~mol} \%$ silica were successfully prepared and the sols produced clear crack free coatings on glass substrates (TiSi 70/30, TiSi 80/20, TiSi $90 / 10$ and $\mathrm{TiO}_{2}$ ). The transmittance curves for the $\mathrm{TiO}_{2}-\mathrm{SiO}_{2}$ 90/10 PEG coating after drying and after autoclaving of dried coating are seen in Figure 2. The figure shows the general trend seen in all the films with different compositions and no obvious difference in transmittance could be observed. All the prepared coatings were hydrophilic, contact angles varying from $60^{\circ}$ to 
$20^{\circ}$ (Figure 3). Pure $\mathrm{TiO}_{2}$ coating with PEG and $\mathrm{TiO}_{2-}$ $\mathrm{SiO}_{2}$ 90/10 coatings with and without PEG exhibit lowest water contact angles (Figure 3). The lowest contact angles were measured for pure $\mathrm{TiO}_{2}$ coating prepared with PEG $\left(\sim 25^{\circ}\right)$ and from the coatings containing only $10 \%$ of $\mathrm{SiO}_{2}$. The use of PEG has the strongest influence on pure $\mathrm{TiO}_{2}$ films, where the contact angle decreased from $55^{\circ}$ to $25^{\circ}$ by PEG addition.

The photocatalytic activity of $\mathrm{TiO}_{2}$ and $\mathrm{TiO}_{2}-\mathrm{SiO}_{2}$ coatings is given as the decomposition rate of methylene blue (Figures 1 and 4). The activity of coatings from original sols without PEG increased with decreasing silica content, showing the highest photocatalytic activity for $\mathrm{TiO}_{2}-\mathrm{SiO}_{2}$ 90/10 coating. The results from the coatings made with PEG showed all the increased photocatalytic activities, but the values may be mostly due to the PEG on the surfaces, rather than the chemistry or morphology of the material. The UV treatment of PEG containing coatings further increased the photocatalytic activity.

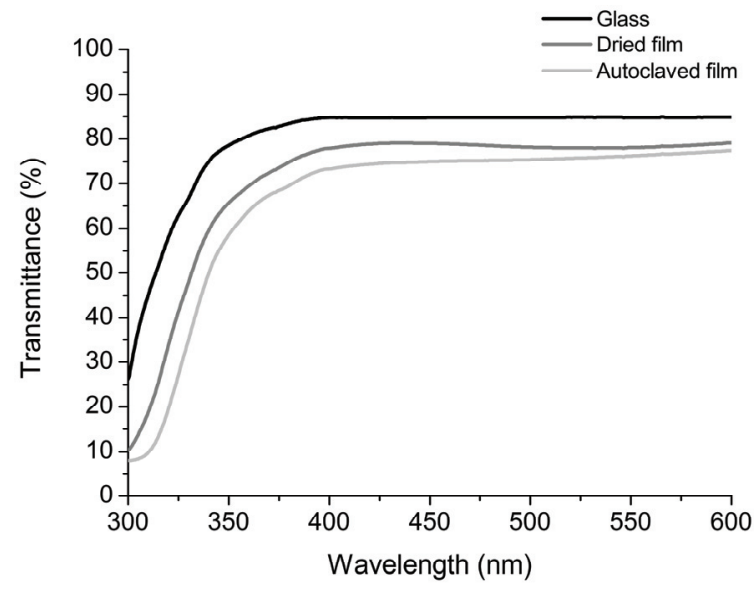

Figure 2. UV-Vis transmittance of $\mathrm{TiO}_{2}-\mathrm{SiO}_{2}$ 90/10 films

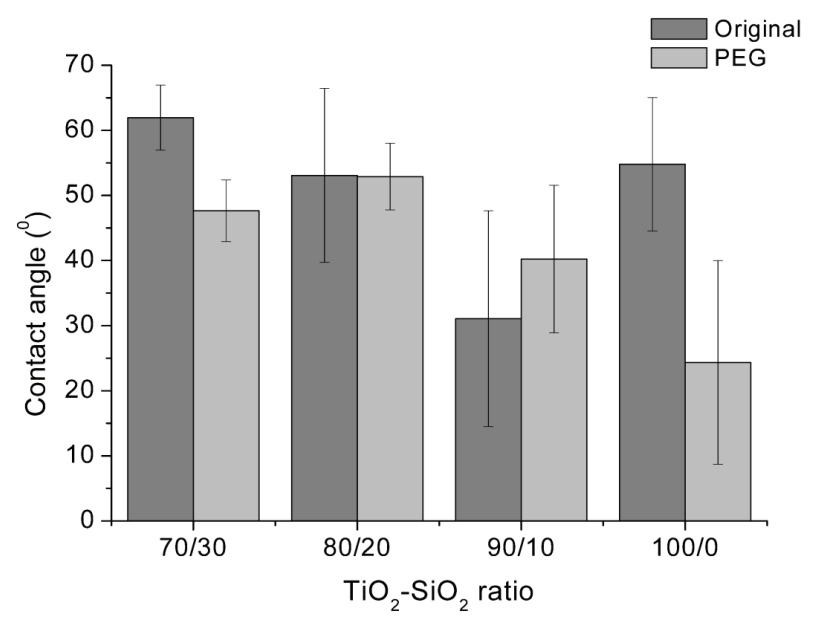

Figure 3. The contact angles of autoclaved films prepared from original and PEG containing sols
After the SBF test the only crack free surface was observed for $\mathrm{TiO}_{2}-\mathrm{SiO}_{2}$ 90/10 made with PEG. The optical microscope pictures from $\mathrm{TiO}_{2}-\mathrm{SiO}_{2}$ 90/10 coating surfaces after SBF test are shown in Figure 5. It shows that the original $\mathrm{TiO}_{2}-\mathrm{SiO}_{2}$ 90/10 coating was cracked during the SBF immersion, but the PEG containing was crack free. The SEM pictures of $\mathrm{TiO}_{2}-\mathrm{SiO}_{2}$ 90/10 films (Figure 6)

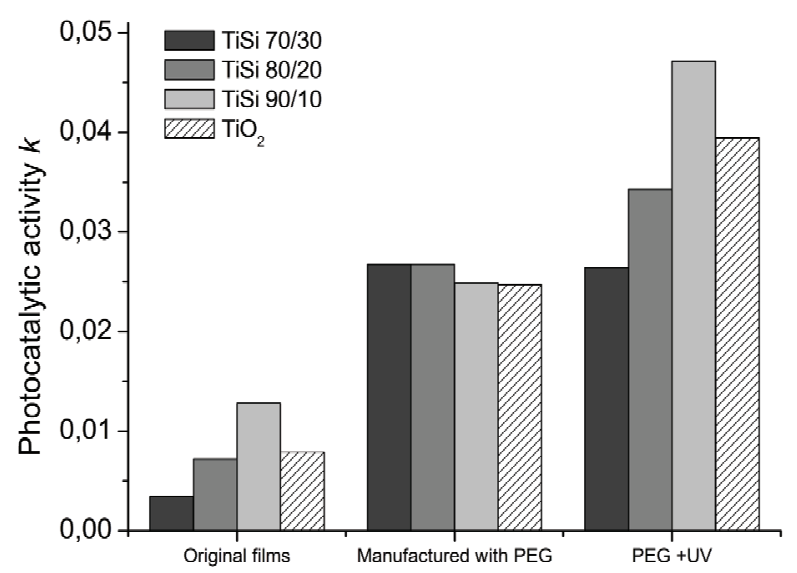

Figure 4. Photocatalytic activity of autoclaved films prepared from original and PEG containing sols and after UVtreatment of films made with PEG (estimated error 10\%)

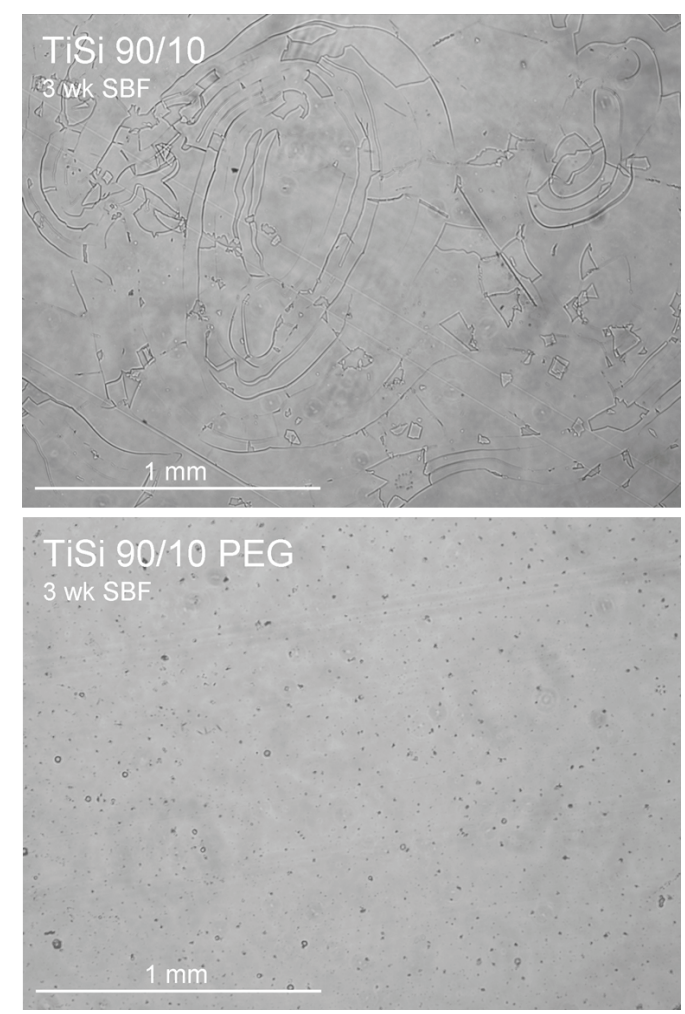

Figure 5. Optical micrographs of autoclaved films after 3 week immersion in $\mathrm{SBF}$. Original $\mathrm{TiO}_{2}-\mathrm{SiO}_{2}$ 90/10 film above and a film made with PEG below 
were taken before and after SBF immersion. The films were consisted of the small granular particles having the size of 20-50 nanometers. $\mathrm{TiO}_{2}-\mathrm{SiO}_{2}$ 90/10 coating made with PEG show smoother structure compared to coating made without PEG, but after SBF immersion the morphology of coatings was similar.

The $\mathrm{TiO}_{2}-\mathrm{SiO}_{2}$ 90/10 coating made with $\mathrm{PEG}$ was chosen to the animal experiment. This coating was hydrophilic, showed photocatalytic activity and had the particle size suitable for biological coatings, thus concluded to compose the best candidate as implant coating.

\subsection{Animal Experiment}

All the implanted samples were available for histological evaluation. In most cases the implants were surrounded by fibrous connective tissue, but occasionally by adipose tissue. A connective tissue layer surrounded all the expe- rimental materials. Also in those cases where an implant was located in the adipose tissue, a connective tissue layer was observed around the implant (Figure 7). The histological scene was characterized by a mild inflammatory cell reaction, with no differences among the three materials. No multinuclear giant cells were noticed in any of the haematoxyline eosine stained slides. The thickness of the connective tissue capsule was very thin around the experimental implants ranging from 2 to 3 cell layers. No difference among the materials was noticed. Uncoated NiTi implants scored highest in the qualitative evaluation of the connective tissue capsule $(3.8 \pm 0.5$ vs $3.3 \pm 0.5$ for both of the coated implants). $\mathrm{TiO}_{2}$ coated implants appeared to have more areas in direct contact with the connective tissue than uncoated or $\mathrm{TiO}_{2}-\mathrm{SiO}_{2}$ coated implants. However, due to high standard deviation this difference did not reach statistical significance (Figure 8).

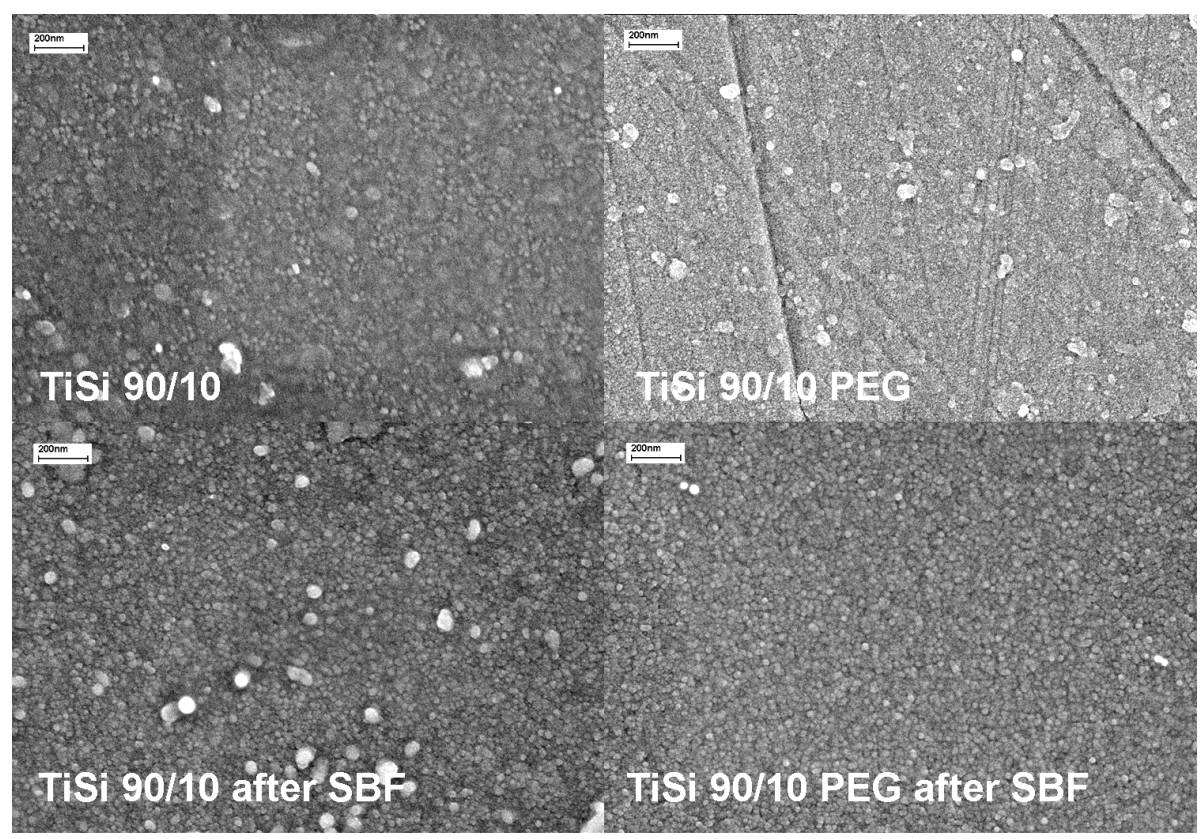

Figure 6. SEM pictures of autoclaved $\mathrm{TiO}_{2}-\mathrm{SiO}_{2}$ 90/10 film without PEG and with it and pictures after SBF immersion. Scale bar is $200 \mathrm{~nm}$
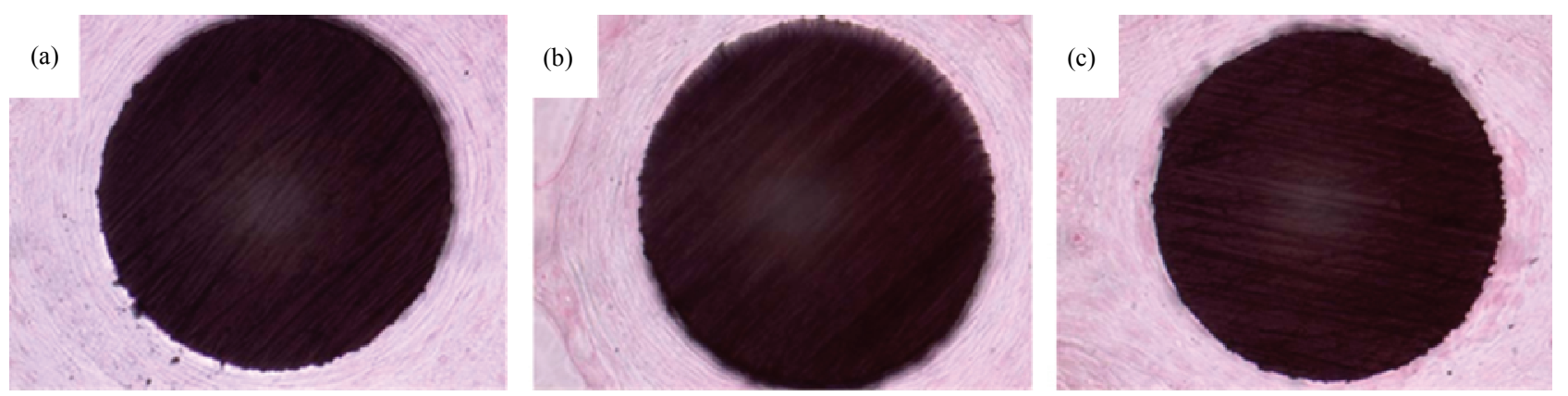

Figure 7. Histological cross-sections of the implants after 4 weeks. HE stain. (a) Uncoated Niti; (b) coated with $\mathrm{TiO}_{2}$; (c) coated with $\mathrm{TiO}_{2}-\mathrm{SiO}_{2}$ 90/10 PEG. The diameter of implant is $220 \mu \mathrm{m}$ 


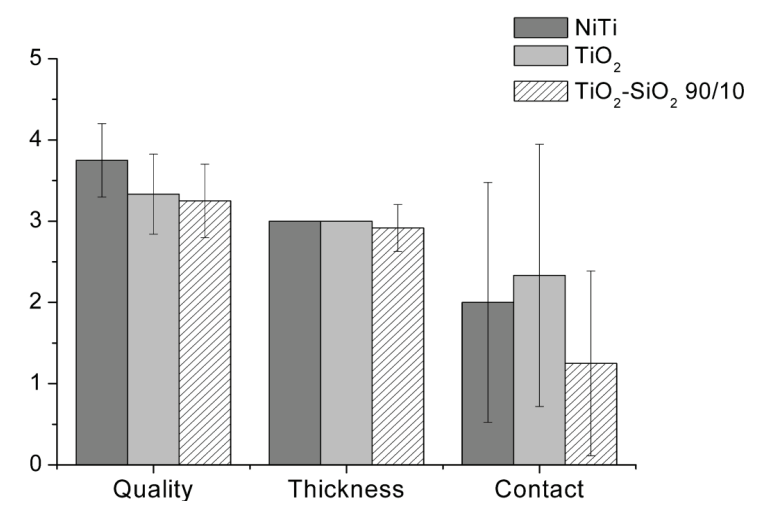

Figure 8. Fibrous tissue capsule formation (0-4): quality and thickness of the capsule and direct implant to tissue contact

\section{Discussion}

In this study a series of low temperature $\mathrm{TiO}_{2}$ and $\mathrm{TiO}_{2}-$ $\mathrm{SiO}_{2}$ sol-gel coatings were first prepared onto microscope glass slides to optimize the low temperature sol-gel film for biological applications. The biological response of sol-gel materials largely depends on their surface properties: topography, hydrophilicity, electronegativity and ionic dissolution in body environment. A comparable evaluation between different sol-gel titania and titania-silica films can be made with contact angle and photocatalytic activity measurements; the results of this study express above mentioned properties all together, thus enabling a ranking according to the surface activity of the coatings. The contact angle of the surface depends on the surface porosity and the possible hydroxyl groups on the surface, while the photocatalytic activity is related to the chemical state of titania and the surface area of the coating. $\mathrm{TiO}_{2}$ is a wide bandgap material $(\mathrm{Eg} 3.2 \mathrm{eV})$ exhibiting photocatalytic activity. The intrinsic photocatalytic activity of $\mathrm{TiO}_{2}$ is directly related with its crystal properties and it is widely known that the photo-induced charges (electrons and holes) are generated in well crystallized phases and preferably in the anatase allotropic form [26,27].

The sol-gel method allows nanoscale mixing of organic and inorganic components. The introduction of organic components into an inorganic sol-gel network usually improves mechanical properties and leads to an easier processing of porous thick films [28-30]. A thick single pure inorganic crack free sol-gel layer is difficult to obtain by dip-coating process. The polyethylene glycol (PEG) can be used to increase the thickness and specific surface area of the films. Such incorporation of inorganic elements at the molecular level to organic polymers has resulted in novel properties such as improved mechanical strength and thermal stability [31]. The lack of absorption bands between 300 and $600 \mathrm{~nm}$ (Figure 2), indicates the high transparency of the film in the visible region. The decreased transmittance after autoclaving is a sign of condensation and increased thickness of the film. The addition of PEG into the sol also slows down the hydrolysis and condensation speed through reducing the free water in the whole sol-gel system and, e.g. the formed $\mathrm{TiO}_{2}$ will not easily form large agglomerates in the film [32]. The PEG content of the sols was $6.4 \mathrm{~g} / 100 \mathrm{ml}$. Small amounts of PEG may be used in sol-gel process without effect on the roughness and pore structure of sol-gel films [33]. Thus the role of PEG in this study seems to be more a processing aid; it does not influence on the particle formation of oxides (Figure 6).

The addition of PEG into the sol markedly increased the photocatalytic results of the coatings. Though, the PEG containing coatings were slightly blue dyed after the test, thus the colour adsorption may have had an effect on the results. The test was also performed with the coatings were preincubated overnight in methylene blue solution before the photocatalytic test, but the results (not shown) were similar. However it was evident, that the activity of $\mathrm{TiO}_{2}-\mathrm{SiO}_{2}$ 90/10 coating was higher than the activity of pure $\mathrm{TiO}_{2}$ film, and the activity diminished with increasing silica content. This indicates that a part of photocatalytic activity of $\mathrm{TiO}_{2}-\mathrm{SiO}_{2}$ 90/10 coating is also chemistry based. In addition, the UV treatment further increased the photocatalytic activity of PEG containing coatings. The trend was same as with the coatings made from original sols, thus giving additional proof of real photocatalytic active sites present in the coatings.

The stability test of the coatings was performed in SBF. The possible dissolution of ions from the surface and the relaxation of intrinsic tensions in the coatings in liquid environment may cause crack formation, especially in the coatings with poor adhesion to the substrate. The $\mathrm{TiO}_{2}-$ $\mathrm{SiO}_{2}$ 90/10 coating made with PEG was the only crack free film after SBF test (Figure 5), which indicates a better stability and/or adhesion compared to other coatings in this study.

The titania content of $\mathrm{TiO}_{2}-\mathrm{SiO}_{2}$ coatings ranged from 100 to $70 \mathrm{~mol} \%$. The titania is able to crystallize in homogeneous, atomically mixed $\mathrm{TiO}_{2}-\mathrm{SiO}_{2}$ oxides, but the amount of $\mathrm{TiO}_{2}$ content is then limited to $20 \mathrm{wt} \%$ [34, 35]. At higher $\mathrm{Ti}$ contents, $\mathrm{TiO}_{2}$ crystallites tend to form a separate phase, demonstrating that silica can not favourably accommodate all the Ti atoms in the network above a certain limit [34 and references therein]. Silicon releasing sol-gel materials can be obtained when $\mathrm{Si}$ atoms are not chemically bonded to the Ti atoms, and there are separate oxide phases in the structure. It is previously shown that the $\mathrm{TiO}_{2}-\mathrm{SiO}_{2}$ 90/10 sol-gel coatings are able to release silica even though the films are heat-treated at $500^{\circ} \mathrm{C}$ [36]. It was concluded that the coatings con- sisted of isolated $\mathrm{TiO}_{2}$ particles surrounded by an amorphous $\mathrm{SiO}_{2}$, possibly cross-linked by Ti-O-Si bonds in a continuous structure. The SEM pictures of $\mathrm{TiO}_{2}-\mathrm{SiO}_{2}$ 90/10 coatings made in the present study, showed quite smooth 
granular structures for coatings made with and without PEG (Figure 6). The slightly smoother structure of the PEG containing coating may derive from the applied PEG, because the original granular structure was revealed after a three week immersion in SBF. The coating structure consisted mainly of those granular particles having the size from 20 to $50 \mathrm{~nm}$, thus exhibiting the morphology shown to favour bioactivity of sol-gel materials $(2-50 \mathrm{~nm})$ [37-39].

The crystallinity of the studied materials was not analysed in this work. X-ray diffraction (XRD) is a preferable method to analyse crystallinity of sol-gel films, but the sensitivity of the equipment is insufficient for analysing thin coatings with very small crystallites. It is shown that the incorporation of the silica onto the titania network can effectively inhibit the crystallite growth of titania or even disrupt the phase transformation from amorphous to anatase or rutile form [40-42].

In the present study different sol-gel derived coatings were fabricated on shape memory alloy sutures. Subcutaneous implantation is often used method to examine biocompatibility of new biomaterials. In terms of biocompatibility both the test and control materials performed equally well in rat subcutaneous environment after a 4 weeks implantation period. The high temperature sol-gel titania coating studied in this work is previously shown to bond to the connective tissue $[3,43]$. In light of this, the new low temperature $\mathrm{TiO}_{2}-\mathrm{SiO}_{2}$ coating is a promising implant coating material. Longer implantation time in more demanding conditions would be needed in order to be able to detect real differences in the biological response, e.g. in terms of the unwanted dissolution of nickel, from these experimental materials.

\section{Conclusions}

Based on this study it can be concluded that biocompatible sol-gel derived coatings can be applied on memory metal sutures. The comparable study of different sol-gel surfaces by contact angle and photocatalytic activity measurements may be used to evaluate the surface activity of the sol-gel biomaterials. The novel low temperature sol-gel $\mathrm{TiO}_{2}-\mathrm{SiO}_{2} 90 / 10$ coating was found to perform equally well with traditional high temperature $\mathrm{TiO}_{2}$ coating in rat subcutaneous environment after a four weeks implantation period.

\section{Acknowledgements}

This work was supported in part by the National Technology Agency of Finland (40222/05, 40171/06). V. Ä. was supported by the Biomaterial and Tissue Engineering Graduate School in Finland.

\section{REFERENCES}

[1] D. Pickup, K. Wetherall, J. Knowles, M. Smith and R.
Newport, "Sol-Gel Preparation and High-Energy XRD Study of $(\mathrm{CaO})_{\mathrm{x}}\left(\mathrm{TiO}_{2}\right)_{0.5-\mathrm{x}}\left(\mathrm{P}_{2} \mathrm{O}_{5}\right)_{0.5}$ Glasses $(\mathrm{x}=0$ and 0.25)," Journal of Materials Science: Materials in Medicine, Vol. 19, No. 4, April 2008, pp. 1661-1668.

[2] P. Saravanapavan, J. R. Jones, S. Verrier, R. Beilby, V. J. Shirtliff, L. L. Hench and J. M. Polak, "Binary CaO- $-\mathrm{SiO}_{2}$ Gel-Glasses for Biomedical Applications," Bio-Medical Materials \& Engineering, Vol. 14, No. 4, December 2004, pp. 467-486.

[3] S. Areva, H. Paldan, T. Peltola, T. Närhi, M. Jokinen and M. Lindén, "Use of Sol-Gel-Derived Titania Coating for Direct Soft Tissue Attachment," Journal of Biomedical Materials Research Part A, Vol. 70A, No. 2, August 2004, pp. 169-178.

[4] C. P. A. T. Klein, P. Li, J. M. A. de Blieck-Hogervorst and K. de Groot, "Effect of Sintering Temperature on Silica Gels and their Bone Bonding Ability," Biomaterials, Vol. 16, No. 9, June 1995, pp. 715-719.

[5] L. Meseguer-Olmo, M. Ros-Nicolás, V. Vicente-Ortega, M. Alcaraz-Baños, M. Clavel-Sainz, D. Arcos, C. V. Ragel, M. Vallet-Regí and Meseguer-Ortiz C., "A Bioactive Sol-Gel Glass Implant for In Vivo Gentamicin Release. Experimental Model in Rabbit," Journal of Orthopaedic Research, Vol. 24, No. 3, March 2006, pp. 454460.

[6] M. Houmard, D. Riassetto, F. Roussel, A. Bourgeois, G. Berthomé, J. C. Joud and M. Langlet, "Enhanced PersiStence of Natural Super-Hydrophilicity in $\mathrm{TiO}_{2}-\mathrm{SiO}_{2}$ Composite Thin Films Deposited via a Sol-Gel Route," Surface Science, Vol. 602, No. 21, November 2008, pp. 3364-3374.

[7] L. L. Hench, I. D. Xynos and J. M. Polak, "Bioactive Glasses for in Situ Tissue Regeneration," Journal of Biomaterials Science-Polymer Edition, Vol. 15, No. 4, April 2004, pp. 543-562.

[8] E. S. Thian, J. Huang, S. M. Best, Z. H. Barber and W. Bonfield, "Silicon-Substituted Hydroxyapatite: The Next Generation of Bioactive Coatings," Materials Science and Engineering: C, Vol. 27, No. 2, March 2007, pp. 251256.

[9] S. Areva, V. Ääritalo, S. Tuusa, M. Jokinen, M. Lindén and T. Peltola, "Sol-Gel-Derived $\mathrm{TiO}_{2}-\mathrm{SiO}_{2}$ Implant CoaTings for Direct Tissue Attachment. Part II: Evaluation of Cell Response," Journal of Materials Science: Materials in Medicine, Vol. 18, No. 8, August 2007, pp. 1633-1642.

[10] D. Böcking, J. Fiedler, R. E. Brenner and R. E. Hüsing. "Cultivation of Human Fibroblasts and Multipotent Mesenchymal Stromal Cells on Mesoporous Silica and Mixed Metal Oxide Films," Journal of Materials Science, Vol. 44, No. 24, December 2009, pp. 6786-6794.

[11] A. Ochsenbein, F. Chai, S. Winter, M. Traisnel, J. Breme and H. F. Hildebrand. "Osteoblast Responses to Different Oxide Coatings Produced by the Sol-Gel Process on Titanium Substrates," Acta Biomaterialia, Vol. 4, No. 5, September 2008, pp. 1506-1517.

[12] V. Muhonen, S. Kujala, A. Vuotikka, V. Ääritalo, T. Peltola, S. Areva, T. Närhi and J. Tuukkanen, "Biocompatib- 
ility of Sol-Gel-Derived Titania-Silica Coated Intramedullary NiTi Nails," Acta Biomaterialia, Vol. 5, No. 2, February 2009, pp. 785-793.

[13] N. B. Morgan, "Medical Shape Memory Alloy Applications-The Market and its Products," Materials Science and Engineering A, Vol. 378, No. 1-2, July 2004, pp. 1623.

[14] M. Es-Souni, M. Es-Souni and H. Fischer-Brandies, "On the Properties of Two Binary Niti Shape Memory Alloys. Effects of Surface Finish on the Corrosion Behaviour and in Vitro Biocompatibility," Biomaterials, Vol. 23, No. 14, July 2002, pp. 2887-2894.

[15] W. Jia, M. W. Beatty, R. A. Reinhardt, T. M. Petro, D. M. Cohen, C. R. Maze, E. A. Strom and M. Hoffman, "Nickel Release from Orthodontic Arch Wires and Cellular Immune Response to Various Nickel Concentrations," Journal of Biomedical Materials Research Part B: Applied Biomaterials, Vol. 48, No. 4, July 1999, pp. 488495.

[16] C. Shih, S. Lin, Y. Chen, Y. Su, S. Lai, G. J. Wu, C. Kwok and K. Ching, "The Cytotoxicity of Corrosion Products of Nitinol Stent Wire on Cultured Smooth Muscle Cells," Journal of Biomedical Materials Research Part A, Vol. 52, No. 2, November 2000, pp. 395-403.

[17] Y. W. Gu, B. Y. Tay, C. S. Lim and M. S. Yong, "Characterization of Bioactive Surface Oxidation Layer on NiTi Alloy," Applied Surface Science, Vol. 252, No. 5, December 2005, pp. 2038-2049.

[18] C. Y. Li, X. J. Yang, L. Y. Zhang, M. F. Chen and Z. D. Cui, "In vivo Histological Evaluation of Bioactive NiTi Alloy after Two Years Implantation," Materials Science and Engineering: C, Vol. 27, No. 1, January 2007, pp. 122-126.

[19] N. Shevchenko, M.-T. Pham and M. F. Maitz, "Studies of Surface Modified NiTi Alloy," Applied Surface Science, Vol. 235, No. 1-2, July 2004, pp. 126-131.

[20] N. Moritz, S. Areva, J. Wolke and T. Peltola, “TF-XRD Examination of Surface-Reactive $\mathrm{TiO}_{2}$ Coatings Produced by Heat Treatment and $\mathrm{CO}_{2}$ Laser Treatment," Biomaterials, Vol. 26, No. 21, July 2005, pp. 4460-4467.

[21] B. Yang, M. Uchida, H. Kim, X. Zhang and T. Kokubo, "Preparation of Bioactive Titanium Metal via Anodic Oxidation Treatment," Biomaterials, Vol. 25, No. 6, March 2004, pp. 1003-1010.

[22] T. Peltola, M. Pätsi, H. Rahiala, I. Kangasniemi and A. Yli-Urpo, "Calcium Phosphate Induction by Sol-GelDerived Titania Coatings on Titanium Substrates in $V i$ tro," Journal of Biomedical Materials Research Part A, Vol. 41, No. 3, September 1998, pp. 504-510.

[23] J. Yu, X. Zhao and Q. Zhao, "Effect of Surface Structure on Photocatalytic Activity of $\mathrm{TiO}_{2}$ Thin Films Prepared by Sol-Gel Method," Thin Solid Films, Vol. 379, No. 1-2, December 2000, pp. 7-14.

[24] T. Kokubo, H. Kushitani, S. Sakka, T. Kitsugi and T. Yamamuro, "Solutions Able to Reproduce in vivo SurfaceStructure Changes in Bioactive Glass-Ceramic A-W", Journal of Biomedical Materials Research, Vol. 24, No. 6,
June 1990, pp. 721-734.

[25] J. A. Jansen, W. J. Dhert, J. P. van der Waerden and A. F. von Recum, "Semi-Quantitative and Qualitative Histologic Analysis Method for the Evaluation of Implant Biocompatibility," Journal of Investigative Surgery, Vol. 7, No. 2, March-April 1994, 123-134.

[26] H. Choi, E. Stathatos and D. D. Dionysiou, "Synthesis of Nanocrystalline Photocatalytic $\mathrm{TiO}_{2}$ Thin Films and Particles Using Sol-Gel Method Modified with Nonionic Surfactants," Thin Solid Films, Vol. 510, No. 1-2, July 2006, pp. 107-114.

[27] M. Langlet, A. Kim, M. Audier and J. M. Herrmann, "Sol-Gel Preparation of Photocatalytic $\mathrm{TiO}_{2}$ Films on Polymer Substrates," Journal of Sol-Gel Science and Technology, Vol. 25, No. 3, December 2002, pp. 223234.

[28] A. Matsuda, Y. Matsuno, M. Tatsumisago and T. Minami, "Changes in Porosity and Amounts of Adsorbed Water in Sol-Gel Derived Porous Silica Films with Heat Treatment," Journal of Sol-Gel Science and Technology, Vol. 20, No. 2, February 2001, pp. 129-134.

[29] Y. Djaoued, S. Badilescu, P. V. Ashrit, D. Bersani, P. P. Lottici and R. Brüning, "Low Temperature Sol-Gel Preparation of Nanocrystalline $\mathrm{TiO}_{2}$ Thin Films," Journal of Sol-Gel Science and Technology, Vol. 24, No. 3, July 2002, 247-254.

[30] Z. Liu, Z. Jin, W. Li and J. Qiu, "Preparation of ZnO Porous Thin Films by Sol-Gel Method Using PEG Template," Materials Letters, Vol. 59, No. 28, December 2005, pp. 3620-3625.

[31] K. Kuraoka, T. Ueda, M. Sato, T, Okamoto and T. E. Yazawa. "Preparation and Properties of Organic-Inorganic Hybrid Flexible Hardcoat Films," Journal of Materials Science, Vol. 40, No. 13, July 2005, pp. 3577-3579.

[32] B. Guo, Z. Liu, L. Hong and H. Jiang, "Sol-Gel Derived Photocatalytic Porous $\mathrm{TiO}_{2}$ Thin Films," Surface and Coatings Technology, Vol. 198, No. 1-3, August 2005, pp. 24-29.

[33] J. Yu, J. C. Yu, B. Cheng, X. Zhao, Z. Zheng and A. S. K. $\mathrm{Li}$, "Atomic Force Microscopic Studies of Porous $\mathrm{TiO}_{2}$ Thin Films Prepared by the Sol-Gel Method," Journal of Sol-Gel Science and Technology, Vol. 24, No. 3, July 2002, pp. 229-240.

[34] X. Gao and I. E. Wachs, "Titania-Silica as Catalysts: Molecular Structural Characteristics and Physicochemical Properties," Catalysis Today, No. 51, No. 2, June 1999, pp. 233-254.

[35] D. M. Pickup, F. E. Sowrey, R. J. Newport, P. N. Gunawidjaja, K. O. Drake and M. E. Smith, "The Structure of $\mathrm{TiO}_{2}-\mathrm{SiO}_{2}$ Sol-Gel Glasses from Neutron Diffraction with Isotopic Substitution of Titanium and ${ }^{17} \mathrm{O}$ and ${ }^{49} \mathrm{Ti}$ Solidstate NMR with Isotopic Enrichment," The Journal of Physical Chemistry B, Vol. 108, No. 30, July 2004, pp. 10872-10880.

[36] V. Ääritalo, S. Areva, M. Jokinen, M. Lindén and T. Peltola, "Sol-Gel-Derived $\mathrm{TiO}_{2}-\mathrm{SiO}_{2}$ Implant Coatings for Direct Tissue Attachment. Part I: Design, Preparation and 
Characterization," Journal of Materials Science: Materials in Medicine, Vol. 18, No. 9, September 2007, pp. 1863-7183.

[37] P. Sepulveda, J. R. Jones and L. L. Hench, "In Vitro Dissolution of Melt-Derived 45S and Sol-Gel Derived 58S Bioactive Glasses," Journal of Biomedical Materials Research Part A, Vol. 61, No. 2, August 2002, pp. 301-311.

[38] M. M. Pereira and L. L. Hench, "Mechanisms of Hydroxyapatite Formation on Porous Gel-Silica Substrates," Journal of Sol-Gel Science and Technology, Vol. 7, No. 1-2, August 1996, pp. 59-68.

[39] T. Peltola, M. Jokinen, H. Rahiala, M. Pätsi, J. Heikkilä, I. Kangasniemi and A. Yli-Urpo, "Effect of Aging Time of Sol on Structure and in Vitro Calcium Phosphate Formation of Sol-Gel-Derived Titania Films," Journal of Biomedical Materials Research Part A, Vol. 51, No. 2, August 2000, pp. 200-208.

[40] C. Kang, L. Jing, T. Guo, H. Cui, J. Zhou and H. Fu, "Mesoporous $\mathrm{SiO}_{2}$-Modified Nanocrystalline $\mathrm{TiO}_{2}$ with
High Anatase Thermal Stability and Large Surface Area as Efficient Photocatalyst," The Journal of Physical Chemistry C, Vol. 113, No. 3, January 2009, pp. 10061013.

[41] H. J. Lee, S. H. Hahn, E. J. Kim and Y. Z. You, "Influence of Calcination Temperature on Structural and Optical Properties of $\mathrm{TiO}_{2}-\mathrm{SiO}_{2}$ Thin Films Prepared by Sol-Gel Dip Coating," Journal of Materials Science, No. 39, No. 11, June 2004, pp. 3683-3688.

[42] C. Xie, Z. Xu, Q. Yang, B. Xue, Y. Du and J. Zhang, "Enhanced Photocatalytic Activity of Titania-Silica Mixed Oxide Prepared via Basic Hydrolyzation," Materials Science and Engineering B, Vol. 112, No. 1, September 2004, pp. 34-41.

[43] H. Paldan, S. Areva, T. Tirri, T. Peltola, T. Lindholm, L. Lassila, L. Pelliniemi, R.-P. Happonen and T. Närhi, "Soft Tissue Attachment on Sol-Gel-Treated Titanium Implants In Vivo," Journal of Materials Science: Materials in Medicine, Vol. 19, No. 3, March 2008, pp. 1283-1290. 